Economica: Jurnal Ekonomi Islam - Volume 8, Nomor 1 (2017): 103 - 130

ISSN: 2085-9325 (print); 2541-4666 (online)

DOI: http://dx.doi.org/10.21580/economica.2017.8.1.1828

\title{
Dampak Indikator Makroekonomi terhadap Dana Pihak Ketiga Perbankan Syariah
}

\author{
Saekhu \\ Universitas Islam Negeri Walisongo Semarang \\ email: saekhu@walisongo.co.id
}

\begin{abstract}
This study was undertaken to analyze the effects of macroeconomic indicators (SBI interest rate, exchange rate, inflation, Indonesia Composite Index and GDP) to deposits liabilities of Islamic Banking in Indonesia. Analysis unit of this study is the Islamic Banking in Indonesia during the period 1998-2008. For the empirical analysis in this study it is used the data on aggregate time series of the monthly period from January 2003 to December 2010. Source data taken from publication of Bank Indonesia, in the form of Annual Report Bank Indonesia, Indonesia Bank Monetary Statement Of Policy, Statistics Economic and Financial Indonesia, Islamic Banking Statistics (Statistik Perbankan Syariah/SPS) and publication report from Badan Pusat Statistik (BPS). This study uses Linear Regression analysis with Ordinary Least Square (OLS) method. The result show that macroeconomic indicators have impact on Funding (deposit liabilities) of Bank Syariah Mandiri, the SBI interest rate have negative impact, while exchange rate, inflation, Indonesia Composite Index and GDP have positive impact. Based on the same method, it shows that GDP has positive on Funding of Islamic Banking in Indonesia.
\end{abstract}

Keywords: macroeconomic indicators; deposits liabilities; funding.

\begin{abstract}
Abstrak: Penelitian ini dilakukan untuk menganalisis dampak indikator makroekonomi (suku bunga SBI, nilai tukar, inflasi, Indeks Harga Saham Gabungan Indonesia dan PDB) terhadap deposito (Dana Pihak Ketiga) Perbankan Syariah di Indonesia. Unit analisis penelitian ini adalah Perbankan Syariah di Indonesia selama periode 1998-2008. Analisis empiris dalam penelitian ini menggunakan data kumpulan waktu agregat periode bulanan dari Januari 2003 sampai Desember 2010. Sumber data diambil dari publikasi Bank Indonesia, berupa Laporan Tahunan Bank Indonesia, Laporan Kebijakan Moneter, Statistik Ekonomi dan Keuangan Indonesia/SEKI), Statistik Perbankan Syariah (SPS) dan laporan publikasi Badan Pusat Statistik (BPS). Penelitian ini menggunakan analisis Regresi Linier dengan metode Ordinary Least Square (OLS). Hasil menunjukkan bahwa indikator makroekonomi berdampak pada pendanaan (deposito) Bank Syariah Mandiri, suku bunga SBI memiliki dampak negatif, sedangkan nilai tukar, inflasi, Indeks Harga Saham Gabungan Indonesia dan PDB berdampak positif. Berdasarkan metode yang sama, PDB positif terhadap Pendanaan Perbankan Syariah di Indonesia.
\end{abstract}

Kata Kunci: indikator makroekonomi; deposito; pendanaan.

Economica: Jurnal Ekonomi Islam - Volume 8, Nomor 1 (2017) 
Saekhu

\section{Pendahuluan}

Salah satu kunci penting dalam mencapai pertumbuhan ekonomi yang sehat adalah sinergi antara sektor moneter, fiskal dan riil. Bila ketiganya dapat disinergikan maka kestabilan ekonomi juga akan terwujud. Sektor moneter meliputi bank sentral dan semua institusi yang menciptakan uang, utamanya bank komersial. Sektor fiskal meliput operasi fiskal pemerintah yang mengatur penerimaan dan belanja pemerintah, defisit anggaran dan pembiayaannya serta hutang negara. Sedangkan sektor riil meliputi aktivitas yang berhubungan dengan permintaan dan penawaran agregat.

Dalam sektor moneter suatu negara, bank komersial adalah komponen yang paling umum dijumpai. Adapun di Indonesia saat ini mengenal berbagai jenis bank. Namun dari sistemnya, dapat dibedakan menjadi dua, yaitu bank konvensional dan bank syariah (dual banking system). Hal ini diakui dan dikenal sejak diberlakukannya UU No. 7 tahun 1992 tentang Perbankan Syariah. Kemudian diperkuat dengan UU No. 10 tahun 1998 sebagai pengganti UU No. 7 tahun 1992, yang diikuti dengan dikeluarkannya sejumlah ketentuan pelaksanaan dalam bentuk Surat Keputusan Direksi Bank Indonesia. Dalam undang-undang tersebut diatur dengan rinci landasan hukum serta jenis-jenis usaha yang dapat dioperasikan dan diimplementasikan oleh bank syariah. Undang-undang tersebut juga memberikan arahan bagi bank-bank konvensional untuk membuka unit usaha syariah atau bahkan mengkonversikan diri menjadi bank syariah secara total.

Pada tahun 1999 dikeluarkan UU No. 23 yang kemudian diamandemen dengan UU No. 3 tahun 2004 tentang Bank Indonesia. Dalam UU tersebut Bank Indonesia mendapat wewenang untuk dapat menjalankan tugasnya berdasarkan prinsip syariah. Posisi perbankan syariah makin diperkuat dengan keluarnya fatwa MUI No. 1 tanggal 24 Januari 2004 mengenai haramnya bunga bank. 
Dampak Indikator Makroekonomi...

Keberadaan undang-undang tersebut telah memberikan kesempatan yang lebih luas untuk pengembangan jaringan perbankan syariah. Langkah yang ditempuh antara lain melalui izin pembukaan Unit Usaha Syariah (UUS) oleh bank umum konvensional atau konversi sebuah bank umum konvensional menjadi bank syariah. Sebagai bagian dari sistem perbankan nasional, industri perbankan syariah diharapkan terus tumbuh serta menunjukkan kinerja yang efektif dan efisien untuk memfasilitasi kegiatan perekonomian masyarakat.

Berbeda dengan bank konvensional yang menerapkan prinsip time value of money sehingga menerapkan bunga atas simpanan yang diterima dan pembiayaan yang diberikan, bank syariah menerapkan konsep yang sama sekali berbeda, yaitu sistem bagi hasil dan jual beli.

Terkait dengan kemampuan bank, khususnya bank syariah, dalam menghimpun dana pihak ketiga dan menyalurkan pembiayaan, bank tentu menghadapi banyak faktor pendukung maupun penghambat. Salah satu faktor yang berpengaruh besar adalah kondisi makroekonomi. Oleh karena itu penting kiranya untuk melihat faktor-faktor makroekonomi apa saja yang memengaruhi perkembangan dana pihak ketiga dan pembiayaan pada perbankan, terutama bank syariah. Kondisi makroekonomi tersebut dapat dilihat dari indikator-indikatornya. Untuk membatasi lingkup permasalahan hanya diambil 5 (lima) indikator makroekonomi, yaitu suku bunga SBI - 1 bulan, inflasi, kurs USD - IDR, IHSG (Indeks Harga Saham Gabungan) dan PDB (Produk Domestik Bruto). Data yang digunakan adalah triwulan (per 3 bulan).

Berdasar permasalahan di atas, maka muncul pertanyaan penelitian yaitu apakah indikator makroekonomi (SBI, inflasi, kurs, IHSG dan PDB) berpengaruh terhadap DPK (Dana Pihak Ketiga) yang dihimpun oleh perbankan syariah. Sedangkan tujuan dari penelitian ini adalah untuk mengetahui pengaruh dari masing-masing indikator makroekonomi (SBI,

Economica: Jurnal Ekonomi Islam - Volume 8, Nomor 1 (2017) | 105 http://journal.walisongo.ac.id/index.php/economica 
Saekhu

inflasi, kurs, IHSG dan PDB) terhadap DPK (Dana Pihak Ketiga) yang dihimpun perbankan syariah.

\section{Landasan Teori}

\section{Suku Bunga SBI - 1 bulan}

Sertifikat Bank Indonesia (SBI) adalah surat berharga yang dikeluarkan oleh Bank Indonesia sebagai pengakuan hutang berjangka waktu pendek (13 bulan) dengan sistem bunga. SBI merupakan salah satu mekanisme yang digunakan oleh Bank Indonesia untuk mengontrol kestabilan nilai Rupiah. Dengan menjual SBI, Bank Indonesia dapat menyerap kelebihan uang primer yang beredar. Tingkat suku bunga yang berlaku pada setiap penjualan SBI ditentukan oleh mekanisme pasar berdasarkan sistem lelang. Sejak awal bulan Juli 2005, Bank Indonesia menggunakan mekanisme "BI rate" (suku bunga BI), yaitu Bank Indonesia mengumumkan target suku bunga SBI yang diinginkan BI untuk pelelangan pada masa periode tertentu. BI rate ini kemudian yang digunakan sebagai acuan para pelaku pasar dalam mengikuti pelelangan. Suku bunga SBI - 1 bulan, merupakan salah satu sasaran operasional BI Rate, dengan pertimbangan :

1. SBI - 1 bulan telah dipergunakan sebagai acuan (benchmark) oleh perbankan dan pelaku pasar di Indonesia dalam berbagai aktivitasnya.

2. Penggunaan SBI - 1 bulan sebagai sasaran operasional akan memperkuat sinyal respon kebijakan moneter yang ditempuh oleh Bank Indonesia.

3. Dengan perbaikan kondisi perbankan dan sektor keuangan, SBI - 1 bulan terbukti mampu mentransmisikan kebijakan moneter ke dalam sektor keuangan dan sektor ekonomi.

SBI pertama kali diterbitkan dengan tingkat diskonto yang ditetapkan secara wajar oleh Bank Indonesia. Selanjutnya untuk lebih meningkatkan peranan SBI sebagai piranti moneter, maka sejak tanggal 23 Juli 1987 Bank 
Dampak Indikator Makroekonomi...

Indonesia mengubah sistem perdagangan SBI melalui sistem lelang. Dengan diberlakukannya UU No.23 Tahun 1999, Bank Indonesia telah menentukan dan mengumumkan sasaran inflasi sebagai sasaran akhir kebijakan moneter atau dikenal dengan Inflation Targeting Framework.

Dengan amandemen UU Bank Indonesia No. 3 Tahun 2004, pemerintah setelah berkoordinasi dengan Bank Indonesia telah menetapkan dan mengumumkan sasaran inflasi untuk jangka pendek dan menengah yang mencerminkan proses penurunan inflasi secara bertahap (gradual disinflation) mengarah pada sasaran inflasi jangka menengah-panjang yang kompetitif dengan negara-negara lain. Meskipun demikian, hingga Juni 2005, operasi moneter masih menggunakan uang primer (base money) sebagai sasaran kebijakan moneter (Bank Indonesia).

\section{Inflasi}

Inflasi adalah suatu proses meningkatnya harga-harga secara umum dan terus menerus (kontinu). Dengan kata lain, inflasi juga merupakan proses menurunnya nilai mata uang secara kontinu. Inflasi adalah proses dari suatu peristiwa, bukan tinggi rendahnya tingkat harga. Artinya tingkat harga yang dianggap tinggi belum tentu menunjukkan inflasi. Inflasi dianggap terjadi jika proses kenaikan harga berlangsung secara terus menerus dan saling mempengaruhi. Istilah inflasi juga digunakan untuk mengartikan peningkatan persediaan uang yang kadangkala dilihat sebagai penyebab meningkatnya harga (Blanchard 2000).

Inflasi yang terjadi memberikan hubungan yang negatif dengan pertumbuhan ekonomi jangka panjang. Menurut Barro dalam Sahminam (2006), inflasi cenderung menghambat pertumbuhan ekonomi. Beberapa jalur utama bagaimana inflasi membebani pertumbuhan ekonomi adalah pertama, karena perusahaan cenderung tidak merubah harga pada saat yang bersamaan dengan inflasi, maka harga relatif antara barang-barang akan

Economica: Jurnal Ekonomi Islam - Volume 8, Nomor 1 (2017) 
Saekhu

berubah. Hal ini nantinya akan membuat hubungan konsumen dengan perusahaan terganggu, yang berakibat pada efisiensi perekonomian. Kedua, inflasi akan lebih mempersulit rumah tangga untuk merencanakan tabungan untuk hari depan, ataupun pembelian rumah atau barang-barang yang tahan lama. Ketiga, inflasi yang tinggi cenderung lebih bergejolak dan menimbulkan ketidakpastian yang lebih besar.

\section{Kurs (Nilai Tukar Rupiah Terhadap US Dollar)}

Nilai tukar merupakan harga mata uang suatu negara terhadap mata uang negara lain. Oleh karena itu, nilai tukar merupakan salah satu alat pengukur kondisi makroekonomi suatu negara, sebab menunjukkan kemampuan relatif perekonomian suatu negara terhadap negara lainnya. Pada saat ini, barometer untuk mengukur kekuatan mata uang di dunia adalah US Dollar (Dolar Amerika).

Pengaruh kurs terhadap kondisi makroekonomi berhubungan dengan tingkat harga berlaku, yang memengaruhi perilaku nasabah dalam menabung dan permintaan terhadap pembiayaan dalam menyikapi fluktuasi nilai kurs. Mankiw (Mankiw 2001) menyatakan, "Jika kurs riil tinggi, barangbarang dari luar negeri relatif lebih murah dan barang-barang domestik lebih mahal. Jika kurs riil rendah, barang-barang dari luar negeri relatif lebih mahal dan barang-barang domestik relatif lebih murah."

\section{IHSG (Indeks Harga Saham Gabungan)}

Indeks Harga Saham Gabungan merupakan salah satu indeks pasar saham yang digunakan oleh Bursa Efek Indonesia sebagai indikator pergerakan harga saham di BEJ. Indeks ini mencakup pergerakan harga seluruh saham biasa dan saham preferen yang tercatat di Bursa Efek Indonesia. Selain IHSG, terdapat beberapa indeks saham yang juga lazim digunakan, diantaranya adalah: indeks sektoral, indeks LQ45, Jakarta Islamic Index (JII) dan Kompas 100. Pergerakan IHSG dipengaruhi oleh berbagai 
Dampak Indikator Makroekonomi...

faktor baik internal maupun eksternal. Pengaruh peristiwa-peristiwa dunia yang terjadi dan pergerakan indeks saham luar negeri menjadi faktor eksternal yang dominan. Sedangkan faktor internal lebih dipengaruhi oleh peristiwa-peristiwa dalam negeri yang terjadi dan pengaruh dari pergerakan variabel-variabel makroekonomi lainnya seperti nilai tukar rupiah terhadap dolar Amerika, tingkat inflasi, suku bunga (deposite rate), suku bunga Sertifikat Bank Indonesia (SBI) dan jumlah uang beredar (money supply).

Banyak faktor yang memengaruhi fluktuasi pergerakan Indeks Harga Saham Gabungan (IHSG). Fluktuasi ini disebabkan oleh pengaruh yang sangat kompleks. Menurut Tandelilin (Tandelilin 2001) perkembangan pasar modal Indonesia dapat dilihat dari gerakan IHSG yang tampaknya sulit dilepaskan begitu saja dari pengaruh berbagai perubahan kondisi makroekonomi, sosial, politik maupun keamanan (Bursa Efek Indonesia).

\section{PDB (Produk Domestik Bruto)}

Produk Domestik Bruto diartikan sebagai nilai keseluruhan semua barang dan jasa yang diproduksi di dalam wilayah tersebut dalam jangka waktu tertentu (biasanya per tahun). PDB berbeda dari Produk Nasional Bruto (PNB) karena memasukkan pendapatan faktor produksi dari luar negeri yang bekerja di negara tersebut. Sehingga PDB hanya menghitung total produksi dari suatu negara tanpa memperhitungkan apakah produksi itu dilakukan dengan memakai faktor produksi dalam negeri atau tidak. Sebaliknya, PNB memerhatikan asal usul faktor produksi yang digunakan.

PDB Nominal atau disebut juga PDB Atas Dasar Harga Berlaku mengacu kepada nilai PDB tanpa memperhatikan pengaruh harga. Sedangkan PDB riil atau disebut juga PDB Atas Dasar Harga Konstan mengoreksi angka PDB nominal dengan memasukkan pengaruh dari harga. PDB dapat dihitung dengan memakai dua pendekatan, yaitu pendekatan pengeluaran dan pendekatan pendapatan.

Economica: Jurnal Ekonomi Islam - Volume 8, Nomor 1 (2017) 
Saekhu

Secara teori, PDB dengan pendekatan pengeluaran dan pendapatan harus menghasilkan angka yang sama. Namun karena dalam praktik menghitung PDB dengan pendekatan pendapatan sulit dilakukan, maka yang sering digunakan adalah dengan pendekatan pengeluaran.

Ada beberapa studi yang telah dilakukan sebelum ini yang terkait dengan penelitian ini. Studi yang dilakukan oleh Ahmad (Kaleem 2000) mengkaji efektivitas instrumen-instrumen moneter dalam sistem perbankan ganda (dual banking system) di Malaysia. Dalam studinya, Ahmad mencoba mengembangkan dan mendefinisikan instrumen-instrumen moneter dalam sistem perbankan ganda di Malaysia serta mengevaluasi permintaan terhadap instrumen-instrumen tersebut. Dengan menggunakan metodologi yang dikembangkan Darrat, Ahmad kemudian membandingkan validitas dan efektivitas instrumen-instrumen moneter Islam dengan yang berbasis bunga untuk kepentingan kebijakan moneter. Untuk mendukung studinya, Ahmad menggunakan data-data bulanan uang beredar (M1 dan M2) serta instrumen kredit (kredit bank), sebagai target dari kegiatan ekonomi di Malaysia. Hasil studinya (Kaleem 2000) menyatakan bahwa untuk tujuan kebijakan moneter dan instrumen-instrumen moneter Islam terbukti memberikan manfaat yang sama dengan konvensional dalam sistem perbankan ganda, seperti yang berlaku di Malaysia.

Sementara Gizycki (Gizycki 2001), menggunakan variabel makroekonomi untuk mengestimasi risiko dan profitabilitas bank. Temuan Gizycki menyatakan bahwa kenaikan tingkat suku bunga dapat meningkatkan kredit macet, sehingga naiknya tingkat suku bunga berarti penurunan profitabilitas. Hal tersebut dikarenakan pengaruh tingkat suku bunga dalam menciptakan penurunan kualitas kredit lebih besar daripada kapasitas bank untuk memperoleh laba.

Jiang, Tang, Law dan Sze (Guorong Jiang 2003) melakukan penelitian mengenai profitabilitas perbankan di Hongkong. Semua variabel 
Dampak Indikator Makroekonomi...

makroekonomi -tingkat pertumbuhan GDP yang tinggi, inflasi dan tingkat bunga riil- berhubungan positif dan signifikan dengan profitabilitas. Kondisi makroekonomi memainkan peranan penting dalam memengaruhi profitabilitas. Antara tahun 1992 sampai 1996 efek inflasi yang rendah diimbangi dengan tingkat suku bunga yang tinggi, sedangkan penurunan GDP riil hanya mendorong efek yang kecil pada profitabilitas, karena operasional bank menunjukkan tingkat efisiensi yang bagus dengan ditunjukkan oleh penurunan rasio pengeluaran non-bunga terhadap total aset dan peningkatan kualitas aset.

Pariyo (Pariyo 2004) melakukan analisis tentang pengaruh variabel makroekonomi yang terdiri atas: 1) SBI, 2) Valuta Asing (USD) dan 3) SWBI terhadap dana pihak ketiga. Hasil yang diperoleh menunjukkan bahwa semua variabel independent berpengaruh secara signifikan terhadap variabel dependent (DPK). Temuan Pariyo ini sejalan dengan hasil penelitian Haron dan Shanmugam (1995), yaitu hubungan tingkat suku bunga bank konvensional dan DPK yang dihimpun. DPK dan SBI - 1 bulan mempunyai korelasi yang negatif. Hal ini berarti bahwa jika SBI - 1 bulan mengalami kenaikan, maka DPK bank syariah akan turun. Sebaliknya apabila SBI-1 bulan rendah, maka jumlah DPK bank syariah akan meningkat. Dengan kata lain, saat SBI naik, maka DPK akan tersalurkan kepada bank umum konvensional dengan tujuan untuk mendapatkan keuntungan yang lebih besar dibandingkan bank syariah.

Hassan dan Bashir (Bashir 2002) meneliti profitabilitas Bank Islam di beberapa negara (43 Bank Islam). Hasil penelitiannya menyatakan bahwa kondisi makroekonomi yang kondusif berpengaruh positif terhadap tingkat profitabilitas Bank Islam. Dengan mengkorelasikan indikator GDP, ditunjukkan bahwa GDP berhubungan positif dengan Bank Islam. Temuan lainnya dilaporkan bahwa inflasi tidak berpengaruh terhadap profitabilitas Bank Islam. Hal tersebut berarti bahwa kinerja Bank Islam tidak dipengaruhi oleh risiko inflasi.

Economica: Jurnal Ekonomi Islam - Volume 8, Nomor 1 (2017) 
Saekhu

Wibowo (Wibowo 2005) menemukan bukti bahwa selain produk domestik bruto, variabel makroekonomi yang dapat memengaruhi kinerja bank syariah adalah suku bunga Bank Indonesia, dalam hal ini adalah suku bunga Sertifikat Bank Indonesia. Sebagaimana diketahui perubahan suku bunga SBI akan mengakibatkan perubahan suku bunga deposito bank konvensional.

\section{Kerangka Pemikiran}

Perkembangan perekonomian suatu negara mengalami siklus yang pada periode tertentu perekonomian tumbuh pesat dan pada periode lain tumbuh melambat atau bahkan mengalami kemunduran. Untuk mengelola dan memengaruhi perkembangan perekonomian agar dapat berlangsung dengan stabil, maka pemerintah suatu negara biasanya melakukan langkahlangkah kebijakan makroekonomi. Kebijakan ini dilakukan sebagai respon dari fluktuasi yang terjadi pada indikator makroekonomi.

Fluktuasi yang terjadi pada indikator makroekonomi, mempunyai pengaruh terhadap saving (simpanan) yang dilakukan oleh masyarakat, sebab saving hanya dapat dilakukan jika masyarakat memiliki kelebihan pendapatan yang akan berpengaruh terhadap jumlah penghimpunan DPK (Dana Pihak Ketiga) pada perbankan. Bank dalam menyikapi perubahan yang terjadi dalam makroekonomi melakukan kebijakan yang sesuai dengan situasi dan kondisi yang ada. Hal ini mengacu kepada analisis risiko yang dialami oleh bank, sebagai lembaga intermediasi yang menyalurkan dana dalam bentuk pembiayaan kepada masyarakat.

Pada bank konvensional, kebijakan dilakukan pada tingkat suku bunga simpanan dan tingkat suku bunga kredit. Sedangkan perbankan syariah melakukan kebijakan dalam menetapkan nisbah. Nisbah yang ditetapkan mengacu kepada tingkat suku bunga yang berlaku. Apabila nisbah yang ditawarkan kepada nasabah tidak kompetitif terhadap suku bunga bank 
Dampak Indikator Makroekonomi...

konvensional, maka dikhawatirkan terjadinya perpindahan nasabah dari bank syariah ke bank konvensional.

\section{Pengaruh Suku Bunga SBI terhadap Dana Pihak Ketiga}

Bila suku bunga SBI naik, maka bank akan meningkatkan imbal hasil atas dana simpanan yang dipercayakan kepadanya. Bank konvensional melakukannya dengan cara menaikkan suku bunga sedangkan bank syariah adalah dengan bagi hasil (nisbah)-nya. Hal tersebut dilakukan agar simpanan bank tetap memberikan imbal hasil tertimbang risiko yang tetap menarik. Mengingat simpanan bank adalah instrumen investasi dengan risiko rendah, masyarakat akan cenderung memindahkan dananya ke simpanan bank bila bunganya naik.

Bila suku bunga SBI turun, maka bank akan cenderung menurunkan (suku bunga pada bank konvensional dan bagi hasil pada bank syariah) untuk mendapatkan marjin (spread) kredit dan simpanan yang lebih besar. Langkah ini dapat ditempuh karena SBI sebagai risk-free instrument yang menjadi pembanding terhadap seberapa menarik suku bunga atau bagi hasil pada bank syariah simpanan turun. Apabila penurunannya dirasakan signifikan oleh nasabah, kondisi ini akan mendorong mereka untuk mencari alternatif yang memberikan imbal hasil tertimbang risiko (return vs risk) yang lebih menarik, dengan asumsi bahwa imbal hasil instrumen investasi lainnya tetap.

Pengaruh suku bunga SBI terhadap dana pihak ketiga pada bank syariah adalah dapat menjaga diri dari pengaruh perubahan suku bunga pasar dan SBI. Mengingat konsep dasar perbankan syariah atas imbal hasil dana pihak ketiga adalah bagi hasil atas hasil pengelolaan dana tersebut. Sedangkan pengelolaan dana tersebut diatur secara ketat oleh ketentuan-ketentuan sehingga sesuai dengan syariat Islam. Sehingga arah dari pengelolaan dana lebih kepada sektor riil. Sektor riil seharusnya jauh dari dampak perubahan suku bunga SBI.

Economica: Jurnal Ekonomi Islam - Volume 8, Nomor 1 (2017) 
Saekhu

\section{Pengaruh Inflasi terhadap Dana Pihak Ketiga}

Bila inflasi naik, maka akan terjadi kenaikan pada harga nominal barang dan jasa. Hal ini menyebabkan daya beli masyarakat akan mengalami penurunan. Pendapatan yang semula dialokasikan sebagai saving akan digunakan sebagian atau seluruhnya untuk kepentingan konsumsi. Karena berkurangnya dana saving secara agregat, bank akan kesulitan dalam mendapatkan dana pihak ketiga.

Bila inflasi turun, maka harga barang dan jasa secara nominal akan mengalami penurunan. Hal ini menyebabkan daya beli masyarakat cenderung mengalami kenaikan. Pendapatan yang semula dialokasikan sebagai konsumsi akan dapat disisihkan sebagai saving. Karena meningkatnya dana saving secara agregat, bank akan lebih mudah dalam mendapatkan dana pihak ketiga.

\section{Pengaruh Kurs terhadap Dana Pihak Ketiga}

Bila kurs naik, maka jika suatu mata uang menguat terhadap mata uang negara lain, sehingga barang produksi atau jasa yang dihasilkan negara itu akan menjadi lebih mahal bila dihitung dengan mata uang negara lain tersebut. Akibatnya permintaan terhadap barang atau jasa diharapkan akan mengalami penurunan dan tidak tertutup kemungkinan adanya penggunaan subtitusi yang pada akhirnya akan semakin menekan permintaan. Permintaan yang menurun akan disikapi oleh produsen dengan menurunkan pasokan sehingga tercapai keseimbangan baru.

Pengurangan pasokan dilakukan dengan mengurangi produksi. Bila produksi mengalami penurunan, masyarakat selaku penerima balas jasa faktor produksi dan perusahaan selaku produsen akan mengalami penurunan pendapatan. Akibatnya dana yang tersedia untuk diinvestasikan dan disimpan akan berkurang. Hal tersebut mengakibatkan bank akan kesulitan dalam melakukan penghimpunan dana pihak ketiga. 
Dampak Indikator Makroekonomi...

Bila kurs turun, maka jika suatu mata uang melemah terhadap mata uang negara lain, sehingga barang produksi atau jasa yang dihasilkan negara itu akan menjadi relatif lebih murah bila dihitung dengan mata uang negara lainnya tersebut. Akibatnya permintaan terhadap barang atau jasa diharapkan akan mengalami kenaikan. Permintaan yang naik akan disikapi oleh produsen dengan meningkatkan pasokan sehingga tercapai keseimbangan baru. Penambahan pasokan dilakukan dengan meningkatkan produksi sehingga ekonomi mengalami percepatan.

Dalam ekonomi yang mengalami pertumbuhan, dana yang tersedia untuk diinvestasikan dan disimpan akan meningkat. Akibatnya bank akan lebih mudah dalam melakukan penghimpunan dana pihak ketiga.

\section{Pengaruh IHSG terhadap Dana Pihak Ketiga}

Bila IHSG naik, maka imbal hasil simpanan bank akan menjadi tidak menarik, akibatnya dana pihak ketiga mengalami penuurunan. Pada saat harga saham-saham naik (tercermin dalam kenaikan IHSG), investasi dalam pasar modal akan memberikan imbal hasil (return) yang lebih menarik dibandingkan dengan investasi dalam bentuk tabungan dan simpanan bank lainnya. Akibatnya masyarakat akan mengalihkan investasinya ke pasar modal.

Bila IHSG turun, maka imbal hasil simpanan bank akan menjadi lebih menarik, akibatnya dana pihak ketiga mengalami kenaikan. Pada saat harga saham-saham turun (tercermin dalam penurunan IHSG), investasi dalam pasar modal akan memberikan imbal hasil (return) yang tidak menarik dibandingkan dengan investasi dalam bentuk tabungan dan simpanan bank lainnya. Apalagi mengingat risiko yang lebih besar dalam pasar modal dibandingkan simpanan bank yang dijamin oleh pemerintah. Akibatnya masyarakat akan mengalihkan investasinya ke simpanan bank.

Economica: Jurnal Ekonomi Islam - Volume 8, Nomor 1 (2017) 
Saekhu

\section{Pengaruh PDB terhadap Dana Pihak Ketiga}

Bila PDB naik, maka hal ini menggambarkan kegiatan produksi dalam negeri yang meningkat. Pada kondisi tersebut masyarakat sebagai pemilik faktor produksi secara agregat akan memperoleh pendapatan yang lebih besar; baik karena peningkatan pendapatan maupun karena perluasan penerima pendapatan. Akibatnya akan semakin banyak dana yang dapat dialokasikan untuk simpanan (saving). Hal ini akan membuat bank lebih mudah menjaring dana masyarakat sehingga dana pihak ketiganya akan mengalami kenaikan.

Bila PDB turun, maka hal ini menggambarkan kegiatan produksi dalam negeri yang mengalami perlambatan. Pada kondisi tersebut masyarakat sebagai pemilik faktor produksi secara agregat akan memperoleh pendapatan yang lebih kecil; baik karena menurunnya pendapatan maupun karena berkurangnya jumlah penerimaan pendapatan. Akibatnya dana yang dapat dialokasikan untuk simpanan (saving) akan mengalami penurunan juga. Hal ini akan membuat bank kesulitan dalam menjaring dana masyarakat sehingga dana pihak ketiganya akan mengalami penurunan.

Sesuai dengan jaringan kerja (network association) yang dijelaskan pada kerangka pemikiran (theoretical framework) di atas, maka hipotesis yang disusun dalam penelitian ini adalah diduga indikator makroekonomi (SBI, inflasi, kurs, IHSG dan PDB) berpengaruh terhadap DPK (Dana Pihak Ketiga) Bank Syariah.

\section{Metode Penelitian}

Cakupan dalam penelitian ini meliputi wilayah di Indonesia. Untuk analisis empiris dalam penelitian ini digunakan data time series triwulanan periode Januari 2003 sampai Desember 2010. Data yang digunakan dalam mengestimasi model tersebut adalah data time series agregat variabel makro dan mikroekonomi. Data dimulai dengan rentang setelah krisis ekonomi 
Dampak Indikator Makroekonomi...

dengan pertimbangan untuk melihat perilaku DPK periode setelah krisis. Sumber data yang akan digunakan berasal dari publikasi Laporan Bank Indonesia, berupa Laporan Perbankan Indonesia, Statistik Ekonomi dan Keuangan Indonesia (SEKI), Statistik Perbankan Syariah (SPS), serta laporan publikasi dari Badan Pusat Statistik (BPS). Data yang digunakan adalah data riil yaitu telah memperhitungkan laju inflasi.

Untuk menyelesaikan permasalahan dalam penelitian ini, digunakan metode kuantitatif dengan terlebih dahulu membuat disain penelitian dalam bentuk model ekonometrika. Model ekonometrika yang digunakan dalam penelitian ini adalah model regresi linier berganda untuk menguji pengaruh variabel bebas terhadap variabel terikat. Model tersebut dibuat untuk mengetahui pengaruh indikator makroekonomi, yang dipergunakan sebagai variabel penelitian adalah suku bunga SBI triwulanan, inflasi year on year, kurs (nilai tukar rupiah terhadap US Dollar), IHSG (Indeks Harga Saham Gabungan) menggunakan data hari terakhir bursa triwulan bersangkutan dan PDB (Produk Domestik Bruto) sebagai variabel bebas. Sedangkan untuk variabel terikatnya adalah DPK (Dana Pihak Ketiga).

Data-data yang digunakan pada penelitian ini merupakan data time series yang dimulai dari bulan Januari 2007 sampai dengan Desember 2014 dengan perincian sebagai berikut:

1. Penyerapan DPK per triwulan diperoleh dari Laporan Keuangan Bank Syariah. Data DPK Bank Syariah terdiri dari: Giro Wadi'ah, Tabungan Muḍarabah dan Deposito Muḍarabah.

2. Tingkat suku bunga SBI - 1 bulan dalam periode triwulanan diambil dari Statistik Ekonomi dan Keuangan Indonesia (SEKI) Bank Indonesia.

3. Nilai kurs tengah USD-IDR pada akhir periode triwulanan diambil dari Statistik Ekonomi dan Keuangan Indonesia (SEKI) Bank Indonesia.

4. Inflasi year on year triwulanan diambil dari Biro Pusat Statistik. 
Saekhu

5. Indeks Harga Saham Gabungan (IHSG) hari bursa terakhir triwulanan diambil dari Bursa Efek Indonesia.

6. Produk Domestik Bruto triwulanan diambil dari Biro Pusat Statistik.

Untuk menguji hipotesis digunakan model regresi dengan metode Regresi Kuadrat Terkecil/OLS (ordinary least square). Model regresi linear digunakan untuk mengetahui pengaruh multivariasi antara variabel tingkat variabel independen terhadap penawaran kredit (Gujarati, 2003). Model dalam penelitian ini adalah:

$$
D P K=f(S B I, K U R S, I N F L A S I, I H S G, P D B)
$$

Secara matematis, model persamaan regresi dalam penelitian ini dapat ditulis:

$$
\mathrm{DPK}_{\mathrm{t}}=\beta_{0}+\beta_{1} \mathrm{SBI}_{\mathrm{t}}+\beta_{2} \mathrm{KURS}_{\mathrm{t}}+\beta_{3} \mathrm{INF}_{\mathrm{t}}+\beta_{4} \mathrm{IHSG}_{\mathrm{t}}+\beta_{5} \mathrm{PDB}_{\mathrm{t}}+\varepsilon_{\mathrm{t}}
$$

Untuk mendapatkan hasil estimasi yang baik dan memenuhi asumsi yang disyaratkan, maka dilakukan pengujian atas asumsi yang digunakan. Pengujian akan dilakukan pada empat asumsi utama yaitu multikolineritas (multicolinierity), heteroskedastistas dan otokorelasi (autocorrelation) serta normalitas residualnya.

\section{Hasil dan Pembahasan}

\section{Statistik Deskriptif Variabel Penelitian}

Berdasarkan hasil analisis deskripsi statistik, maka dalam tabel 1 berikut ini akan ditampilkan karakteristik sampel yang digunakan didalam penelitian ini meliputi: jumlah sampel $(\mathrm{N})$, rata-rata sampel (mean), nilai maksimum, nilai minimum serta standar deviasi $(\sigma)$ untuk masing-masing variabel. 
Dampak Indikator Makroekonomi...

Tabel 1. Deskripsi Variabel Penelitian

Descriptive Statistics

\begin{tabular}{lrrrrr}
\hline & N & Minimum & Maximum & Mean & Std. Deviation \\
\hline DPK & 32 & 3322849 & $8 . \mathrm{E} 7$ & $2.62 \mathrm{E7}$ & $1.915 \mathrm{E7}$ \\
SBI & 32 & 0 & 0 & .09 & .019 \\
KURS & 32 & 8285 & 11575 & 9342.62 & 677.013 \\
INF & 32 & 0 & 0 & .08 & .037 \\
IHSG & 32 & 398.00 & 3704.00 & $1.6966 \mathrm{E} 3$ & 887.79523 \\
PDB & 32 & 496.25 & 1669.15 & $9.8026 \mathrm{E} 2$ & 385.92680 \\
Valid N & 32 & & & & \\
(listwise) & & & & & \\
\hline
\end{tabular}

Dari hasil pengujian hipotesis diperoleh nilai adjusted $R^{2}$ sebesar 0,986, dengan demikian dapat disimpulkan bahwa variabel independen bisa menjelaskan sebesar 98,6 persen terhadap variabel dependen, sedangkan sisanya sebesar 1,4 persen dijelaskan oleh faktor lain di luar model persamaan regresi.

Tabel 2. Hasil Pengujian Koefesien Determinasi

Model Summaryb

\begin{tabular}{lrrrr}
\hline Model & R & R Square & \multicolumn{1}{c}{$\begin{array}{c}\text { Adjusted R } \\
\text { Square }\end{array}$} & $\begin{array}{c}\text { Std. Error of the } \\
\text { Estimate }\end{array}$ \\
\hline 1 & $.994^{\mathrm{a}}$ & .989 & .986 & .09854
\end{tabular}

a. Predictors: (Constant), LPDB, LINF, LKURS, LSBI, LIHSG

b. Dependent Variable: LDPK

Hasil perhitungan parameter individual t statistik dapat dilihat pada tabel 3 berikut ini:

Economica: Jurnal Ekonomi Islam - Volume 8, Nomor 1 (2017) 
Tabel 3. Hasil Perhitungan Pengujian Parameter Individual

Coefficients $^{a}$

\begin{tabular}{|c|c|c|c|c|c|c|}
\hline & & \multicolumn{2}{|c|}{$\begin{array}{c}\text { Unstandardized } \\
\text { Coefficients }\end{array}$} & \multirow{2}{*}{$\begin{array}{c}\text { Standardized } \\
\text { Coefficients }\end{array}$} & \multirow[b]{2}{*}{$\mathbf{t}$} & \multirow[b]{2}{*}{ Sig. } \\
\hline \multicolumn{2}{|c|}{ Model } & B & Std. Error & & & \\
\hline \multirow[t]{6}{*}{1} & (Constant) & -10.652 & 2.710 & & -3.930 & .001 \\
\hline & LSBI & -.462 & .155 & -.119 & -2.982 & .006 \\
\hline & LKURS & 1.638 & .314 & .135 & 5.218 & .000 \\
\hline & LINF & .133 & .069 & .072 & 1.927 & .065 \\
\hline & LIHSG & .589 & .084 & .407 & 6.984 & .000 \\
\hline & LPDB & 1.084 & .127 & .521 & 8.527 & .000 \\
\hline
\end{tabular}

a. Dependent Variable: LDPK

Berdasar hasil pengujian di atas, nampak bahwa semua variabel mempunyai signifikansi kurang dari 0.05 ( $\mathrm{p}<0.05)$. Dengan demikian dapat dikatakan bahwa variabel indikator makroekonomi yang terdiri dari SBI, KURS, INFLASI, IHSG, dan PDB berpengaruh terhadap DPK (Dana Pihak Ketiga) Bank Syariah.

Untuk memastikan kelayakan model sehingga model adalah BLUE, maka dilakukan pengujian asumsi sebagai berikut:

\section{Normalitas}

Pengujian normalitas data secara analisis statistik dilakukan dengan menggunakan Uji Kolmogorov-Smirnov. Secara multivariat pengujian normalitas data dilakukan terhadap nilai residualnya. Data yang berdistribusi normal ditunjukkan dengan nilai asymptotic significance diatas 0,05 (Ghozali, 2007). Hasil pengujian normalitas data terlihat dalam Tabel 4 berikut ini: 
Dampak Indikator Makroekonomi...

Tabel 4. Pengujian Normalitas dengan Uji Kolmogorov-Smirnov

One-Sample Kolmogorov-Smirnov Test

\begin{tabular}{llr}
\hline & & $\begin{array}{c}\text { Unstandardized } \\
\text { Residual }\end{array}$ \\
\hline $\mathrm{N}$ & Mean & 32 \\
& Std. Deviation & .0000000 \\
Mormal Parameters ${ }^{\mathrm{a}}$ & Absolute & .09024533 \\
& Positive & .129 \\
& Negative & .086 \\
Kolmogorov-Smirnov Z & &. .129 \\
Asymp. Sig. (2-tailed) & & .730 \\
\hline a. Test distribution is Normal. & & .661 \\
\hline
\end{tabular}

Berdasarkan tabel pengujian normalitas, tampak bahwa residual dalam penelitian ini mengikuti distribusi normal dengan nilai asymptonic significance sebesar 0,661 yang lebih dari 5 persen.

\section{Autokorelasi}

Pengujian autokorelasi juga dilakukan dengan menggunakan uji Breusch Godfrey (uji BG) atau dikenal dengan metode Langrange Multiple (LM). Uji ini dilakukan dengan membentuk variabel lag residual sampai dengan 16 (enam belas) lag. Uji LM akan menghasilkan statistic BreuschGodfrey (BG). BG test dilakukan dengan meregresi variabel pengganggu (residual) Ut menggunakan autoregressive model dengan orde $p$.

Economica: Jurnal Ekonomi Islam - Volume 8, Nomor 1 (2017) 
Saekhu

Tabel 5. Hasil pengujian Autokorelasi dengan LM Test

Autocorrelations

Series: Unstandardized Residual

\begin{tabular}{|c|c|c|c|c|c|}
\hline \multirow[b]{2}{*}{ Lag } & \multirow[b]{2}{*}{ Autocorrelation } & \multirow[b]{2}{*}{ Std. Error ${ }^{a}$} & \multicolumn{3}{|c|}{ Box-Ljung Statistic } \\
\hline & & & Value & df & Sig. ${ }^{b}$ \\
\hline 1 & .150 & .169 & .788 & 1 & .375 \\
\hline 2 & -.178 & .166 & 1.940 & 2 & .379 \\
\hline 3 & -.086 & .163 & 2.220 & 3 & .528 \\
\hline 4 & .032 & .160 & 2.260 & 4 & .688 \\
\hline 5 & -.053 & .158 & 2.372 & 5 & .796 \\
\hline 6 & .005 & .155 & 2.373 & 6 & .882 \\
\hline 7 & -.084 & .152 & 2.682 & 7 & .913 \\
\hline 8 & .147 & .149 & 3.660 & 8 & .886 \\
\hline 9 & -.026 & .145 & 3.691 & 9 & .931 \\
\hline 10 & -.418 & .142 & 12.346 & 10 & .263 \\
\hline 11 & -.163 & .139 & 13.723 & 11 & .249 \\
\hline 12 & .071 & .136 & 14.000 & 12 & .301 \\
\hline 13 & -.032 & .132 & 14.060 & 13 & .370 \\
\hline 14 & -.091 & .129 & 14.564 & 14 & .409 \\
\hline 15 & -.131 & .125 & 15.668 & 15 & .404 \\
\hline 16 & .022 & .121 & 15.702 & 16 & .474 \\
\hline
\end{tabular}

a. The underlying process assumed is independence (white noise).

b. Based on the asymptotic chi-square approximation.

Dari tabel 5 terlihat bahwa hasil statistik Ljung Box jelas bahwa 16 (enam belas) lag ternyata semuanya tidak terdapat variabel lag yang signifikan. Dari hasil pengujian tersebut dapat disimpulkan bahwa dalam model penelitian ini tidak terjadi gejala autokorelasi. 
Dampak Indikator Makroekonomi...

\section{Heteroskedastisitas}

Untuk mendeteksi ada atau tidaknya heterokedastisitas dapat dilakukan dengan menggunakan uji Glejser. Uji Glejser test adalah salah satu uji statistik digunakan untuk mendeteksi ada tidaknya heteroskedastisitas. Glejser menyarankan untuk meregresi nilai absolut dari $\varepsilon_{i t}$ terhadap variabel independen (variabel bebas) yang diperkirakan mempunyai hubungan yang erat dengan $\delta_{i}^{2}$

Tabel 6. Hasil Uji Heteroskedastisitas Dengan Uji Glejser

\begin{tabular}{|c|c|c|c|c|c|c|}
\hline \multicolumn{7}{|c|}{ Coefficients $^{a}$} \\
\hline & & \multicolumn{2}{|c|}{$\begin{array}{l}\text { Unstandardized } \\
\text { Coefficients }\end{array}$} & \multirow{2}{*}{$\begin{array}{c}\text { Standardized } \\
\text { Coefficients }\end{array}$} & \multirow[b]{2}{*}{$\mathbf{t}$} & \multirow[b]{2}{*}{ Sig. } \\
\hline \multicolumn{2}{|c|}{ Model } & B & Std. Error & & & \\
\hline 1 & (Constant) & .091 & 1.315 & & .069 & .946 \\
\hline & LSBI & .135 & .075 & .624 & 1.795 & .184 \\
\hline & LKURS & .021 & .152 & .031 & .139 & .891 \\
\hline & LINF & -.051 & .033 & -.503 & -1.539 & .136 \\
\hline & LIHSG & .047 & .041 & .588 & 1.155 & .258 \\
\hline & LPDB & -.052 & .062 & -.450 & -.844 & .406 \\
\hline
\end{tabular}

a. Dependent Variable: ABS_RESID

Berdasar hasil yang ditunjukkan dalam tabel 6 di atas, nampak bahwa semua variabel bebas menunjukkan hasil yang tidak signifikan, sehingga dapat disimpulkan bahwa semua variabel bebas tersebut tidak terjadi heteroskedastisitas dalam varian kesalahan.

\section{Pengaruh Indikator Makroekonomi terhadap Dana Pihak Ketiga Bank Syariah}

Berdasarkan dari hasil pengujian statistik yang dilakukan, diketahui bahwa indikator makroekonomi berpengaruh terhadap Dana Pihak Ketiga Bank Syariah. Hasil tersebut dapat diuraikan sebagai berikut:

Economica: Jurnal Ekonomi Islam - Volume 8, Nomor 1 (2017) 
Saekhu

\section{Pengaruh Suku Bunga SBI terhadap Dana Pihak Ketiga Bank Syariah}

Dari hasil analisis diketahui bahwa koefisien variabel suku bunga SBI adalah negatif, yang berarti setiap kenaikan pada suku bunga SBI akan menurunkan Dana Pihak Ketiga Bank Syariah. Bila suku bunga SBI naik, maka Bank Syariah seharusnya menaikkan bagi hasil atau nisbah untuk nasabah sebagai langkah mengimbangi bank konvensional yang menaikkan suku bunga. Kondisi ini akan menjadikan simpanan pada Bank Syariah sebagai pilihan investasi yang menarik, maka dana pihak ketiga akan meningkat. Sehingga untuk menginterpretasikan hasil uji statistik tersebut, bukan pengaruh secara langsung, tetapi semata-mata karena Bank Syariah melakukan strategi dalam penghimpunan Dana Pihak Ketiga, agar terhindar dari akibat yang ditimbulkan oleh kenaikan suku bunga SBI seperti yang terjadi di bank konvensional.

Sedangkan bila suku bunga SBI turun, sebagaimana bank konvensional, penyimpan dana di Bank Syariah juga akan melihat suku bunga SBI sebagai pembanding (benchmark), mengimbangi bank konvensional yang menaikkan suku bunga. Jika perubahannya dirasakan signifikan oleh nasabah, kondisi ini akan menjadikan simpanan bank akan menjadi pilihan investasi yang kurang menarik, sehingga Dana Pihak Ketiga Bank Syariah akan mengalami penurunan. Maka Bank Syariah seharusnya menurunkan bagi hasil (nisbah) bagi nasabah sebagai langkah untuk mendapatkan marjin keuntungan yang lebih besar.

\section{Pengaruh Inflasi terhadap Dana Pihak Ketiga Bank Syariah}

Dari hasil analisis diketahui bahwa koefisien variabel inflasi adalah positif, yang berarti setiap kenaikan pada inflasi akan meningkatkan Dana Pihak Ketiga Bank Syariah. Bila inflasi naik, maka Bank Syariah seharusnya dapat lebih fleksibel dalam menghadapi kenaikan inflasi. Mengingat Bank 
Dampak Indikator Makroekonomi...

Syariah menggunakan konsep bagi hasil, sehingga seharusnya tidak terikat dengan patokan BI Rate.

Sedangkan dalam kondisi inflasi turun, dana masyarakat yang akan dialokasikan dalam bentuk dana pihak ketiga umumnya meningkat. Bank Syariah dapat melakukan sosialisasi mengenai sistem ekonomi Islam yang apabila diterapkan sepenuhnya tidak akan terpengaruh oleh inflasi. Sehingga masyarakat mau menempatkan dananya karena yakin bahwa investasinya aman dari inflasi.

\section{Pengaruh Kurs terhadap Dana Pihak Ketiga Bank Syariah}

Dari hasil analisis diketahui bahwa koefisien variabel kurs adalah positif, yang berarti setiap kenaikan pada inflasi akan meningkatkan Dana Pihak Ketiga Bank Syariah. Bila kurs naik, maka barang produksi atau jasa yang dihasilkan negara itu akan menjadi lebih mahal bila dihitung dengan mata uang negara lain tersebut. Akibatnya permintaan terhadap barang atau jasa diharapkan akan mengalami penurunan dan tidak tertutup kemungkinan adanya penggunaan subtitusi yang pada akhirnya akan semakin menekan permintaan. Permintaan yang menurun akan disikapi oleh produsen dengan menurunkan pasokan sehingga tercapai keseimbangan baru. Pengurangan pasokan dilakukan dengan mengurangi produksi. Bila produksi mengalami penurunan, maka masyarakat selaku penerima balas jasa faktor produksi dan perusahaan selaku produsen akan mengalami penurunan pendapatan. Akibatnya dana yang tersedia untuk diinvestasikan dan disimpan akan berkurang. Hal tersebut mengakibatkan bank akan kesulitan dalam melakukan penghimpunan dana pihak ketiga.

Sedangkan dalam kondisi kurs turun, maka barang produksi atau jasa yang dihasilkan negara itu akan menjadi relatif lebih murah bila dihitung dengan mata uang negara lainnya tersebut. Akibatnya permintaan terhadap barang atau jasa diharapkan akan mengalami kenaikan. Permintaan yang

Economica: Jurnal Ekonomi Islam - Volume 8, Nomor 1 (2017) 
Saekhu

naik akan disikapi oleh produsen dengan meningkatkan pasokan sehingga tercapai keseimbangan baru. Penambahan pasokan dilakukan dengan meningkatkan produksi sehingga ekonomi mengalami percepatan. Dalam ekonomi yang mengalami pertumbuhan, dana yang tersedia untuk diinvestasikan dan disimpan akan meningkat. Akibatnya bank akan lebih mudah dalam melakukan penghimpunan dana pihak ketiga.

\section{Pengaruh IHSG terhadap Dana Pihak Ketiga Bank Syariah}

Dari hasil analisis diketahui bahwa koefisien variabel IHSG adalah positif, yang berarti setiap kenaikan pada IHSG akan meningkatkan Dana Pihak Ketiga Bank Syariah. Bila IHSG naik, maka bagi hasil simpanan Bank Syariah akan menjadi tidak menarik, akibatnya dana pihak ketiga mengalami penurunan. Pada saat harga saham-saham naik (tercermin dalam kenaikan IHSG), investasi dalam pasar modal akan memberikan imbal hasil (return) yang lebih menarik dibandingkan dengan investasi dalam bentuk tabungan dan simpanan bank lainnya. Akibatnya masyarakat akan mengalihkan investasinya ke pasar modal.

Sedangkan bila IHSG turun, maka imbal hasil simpanan bank akan menjadi lebih menarik, akibatnya dana pihak ketiga mengalami kenaikan. Pada saat harga saham - saham turun (tercermin dalam penurunan IHSG), investasi dalam pasar modal akan memberikan imbal hasil (return) yang tidak menarik dibandingkan dengan investasi dalam bentuk tabungan dan simpanan bank lainnya. Apalagi mengingat risiko yang lebih besar dalam pasar modal dibandingkan simpanan bank yang dijamin oleh pemerintah. Akibatnya masyarakat akan mengalihkan investasinya ke simpanan bank, sehingga dana pihak ketiga akan meningkat. 
Dampak Indikator Makroekonomi...

\section{Pengaruh PDB terhadap Dana Pihak Ketiga Bank Syariah}

Dari hasil analisis diketahui bahwa koefisien variabel PDB adalah positif, yang berarti setiap kenaikan pada PDB akan meningkatkan Dana Pihak Ketiga Bank Syariah. Bila PDB naik, maka menggambarkan kegiatan produksi dalam negeri yang meningkat. Pada kondisi tersebut masyarakat sebagai pemilik faktor produksi secara agregat akan memperoleh pendapatan yang lebih besar; baik karena peningkatan pendapatan maupun karena perluasan penerimaan pendapatan. Akibatnya akan semakin banyak dana yang dapat dialokasikan untuk simpanan (saving) pada bank. Hal ini akan membuat bank lebih mudah menjaring dana masyarakat sehingga dana pihak ketiganya akan mengalami peningkatan.

Sedangkan bila PDB turun, maka menggambarkan kegiatan produksi dalam negeri yang mengalami perlambatan. Pada kondisi tersebut masyarakat sebagai pemilik faktor produksi secara agregat akan memperoleh pendapatan yang lebih kecil; baik karena menurunnya pendapatan maupun karena berkurangnya jumlah penerima pendapatan. Akibatnya dana yang dapat dialokasikan untuk simpanan (saving) akan mengalami penurunan juga. Hal ini akan membuat bank kesulitan dalam menjaring dana masyarakat sehingga dana pihak ketiganya akan mengalami penurunan.

\section{Simpulan}

Berdasarkan penelitian dan analisis yang dilakukan, ada beberapa hal yang dapat diambil sebagai kesimpulan, yaitu:

1. Penelitian menunjukkan bahwa pengaruh yang diberikan oleh indikator makroekonomi terhadap DPK (Dana Pihak Ketiga) dan Pembiayaan pada Bank Syariah yaitu variabel suku bunga SBI berpengaruh secara negatif, sedangkan variabel lainnya (inflasi, kurs, IHSG dan PDB) memberikan pengaruh yang positif.

Economica: Jurnal Ekonomi Islam - Volume 8, Nomor 1 (2017) 
Saekhu

2. Dari empat variabel yang memiliki pengaruh positif, variabel PDB memiliki pengaruh secara positif dan signifikan terhadap peningkatan DPK (Dana Pihak Ketiga) dan Pembiayaan Bank Syariah. Hubungan antara PDB dengan DPK dan pembiayaan adalah bahwa PDB yang meningkat menggambarkan kegiatan produksi dalam negeri yang mengalami kenaikan. Pada kondisi tersebut masyarakat sebagai pemilik faktor produksi secara agregat akan memperoleh pendapatan yang lebih besar. Sehingga semakin banyak dana yang dapat dialokasikan untuk simpanan (saving). Hal tersebut berpengaruh terhadap DPK Bank Syariah. Dari sisi pembiayaan, kenaikan produksi akan memicu kebutuhan perusahaan selaku produsen terhadap modal kerja dan dana investasi. Akibat dari kebutuhan tersebut, pembiayaan yang dapat disalurkan bank juga akan meningkat. Sedangkan pada kondisi PDB yang menurun, hal yang sebaliknya akan terjadi.

Berdasarkan analisis dan kesimpulan dari penelitian yang dilakukan, ada beberapa saran yang dapat diberikan pada penelitian ini, antara lain:

1. Indikator makroekonomi yang diambil dalam penelitian ini (SBI, kurs, inflasi, IHSG dan PDB) memberikan pengaruh terhadap DPK dan pembiayaan Bank Syariah. Oleh karena itu, Bank Syariah sebaiknya memasukkan indikator-indikator tersebut ke dalam faktor-faktor yang memengaruhi kebijakan penghimpunan DPK dan penyaluran pembiayaan yang diambilnya. Tujuannya agar kebijakan yang dibuat bersifat responsif terhadap indikator makroekonomi yang memengaruhinya sehingga Bank Syariah dapat mempertahankan bahkan meningkatkan kinerjanya.

2. Penelitian memberikan hasil bahwa PDB memberikan pengaruh positif yang paling besar terhadap Dana Pihak Ketiga dan Pembiayaan Bank Syariah. Oleh karena itu Bank Syariah dalam menerapakan saran nomor satu di atas, sebaiknya memberikan bobot yang lebih besar bagi PDB dalam model atau perhitungan yang menjadi dasar penentuan kebijakan penghimpunan DPK dan penyaluran pembiayaan. 
Dampak Indikator Makroekonomi...

\section{Daftar Pustaka}

Blanchard, Olivier. 2000. Economics. New Jersey: Prentice Hall International, Inc..

Enders, Walter. 1995. Applied Econometric Time Series, First Edition, John Willey \& Sons, Inc.

Gizycki, Marianne. 2001. "The Effect of Macroeconomic Condition on Banks Risk and Profitability." Research Discussion Paper, System Stability Department, Reserve Bank of Australia.

Gujarati, Damodar N. 2003. Basic Econometrics, Four Edition, New York, McGraw Hill, USA.

Guorong Jiang, Nancy Tang, Eve Law and Angela Sze. 2003. "The Profitability of the Banking Sector in Hong Kong." Hong Kong Monetary Authority Quarterly Bulletin, September.

Hartadi Sarwono dan Perry Warjiyo. 1998. "Kebijakan Makroekonomi dalam Pemulihan Perekonomian." Diktat Sespibi XXIII.

JJ Manurung, AH Manurung, FD Saragih. 2005. Ekonometrika: Teori dan Aplikasi. Jakarta, Elex Media Komputindo.

Kaleem, Ahmad. 2000. "Modeling Monetary Stability Under Dual Banking System: The Case of Malaysia." International Journal of Islamic Financial Service 2, No. 1 (Apr-Jun).

Karim, Adiwarman Azwar. 2006. Bank Islam: Analisis Fiqh dan Keuangan, Edisi Ketiga. Jakarta: Rajawali Press.

— 2002. Ekonomi Islam Suatu Kajian Ekonomi Makro. Jakarta: The International Institute of Islamic Thought Indonesia.

Mankiw, Gregory. 2001. Principles of Economics, Second Edition. New York: Harcourt College Publishers.

M. Kabir Hassan and Abdel-Hameed M. Bashir. 2002. "Determinants of Islamic Banking Profitability." International Journal.

Michael Gerlach, Wensheng Peng, and Chang Shu. 2002. Macroeconomics Conditions and Banking Performance in Hongkong SAR: A Panel Study. HIKMA, Hongkong.

Economica: Jurnal Ekonomi Islam - Volume 8, Nomor 1 (2017) 
Saekhu

Muhammad. 2002. Kebijakan Fiskal dan Moneter dalam Ekonomi Islami. Jakarta: Penerbit Salemba Empat.

Nachrowi Djalal Nachrowi dan Hardius Usman. 2005. Penggunaan Teknik Ekonometri. Jakarta: Rajagrafindo Persada.

_ 2006. Pendekatan Populer dan Praktis Ekonometrika untuk Analisis Ekonomi dan Keuangan. Jakarta: LPFE Universitas Indonesia.

Pariyo. 2004. "Variabel Makroekonomi Yang Mempengaruhi Penghimpunan Dana Pihak Ketiga (Studi Kasus Bank Muamalat Indonesia Periode 2000-2003)." Disertasi, Program Studi Timur Tengah dan Islam, Universitas Indonesia.

Richard Levin and David Rubin. 1998. Statistics For Management, Seventh Edition. New Jersey: Prentice-Hall International, Inc.

Sekaran, Uma. 2000. Research Methods for Business: A Skill Building Approach. Third Edition, New York, John Willey \& Son, Inc.

Sholichah, Atta Mara Ati. 2007. "Hubungan Kausalitas Granger antara Variabel Ekonomi Makro dengan Perbankan Syariah Indonesia." Tesis Pasca Sarjana UI.

Sudin Haron dan Norafifah Ahmad. 1997. "The Effects of Conventional Interest Rates and Rate of Profit on Funds Deposit with Islamic Banking System in Malaysia", International Journal of Islamic Financial Services, Vol. 1 No. 4.

Sudjono. 2005. "Analisis Keseimbangan dan Hubungan Simultan Antara Variabel Ekonomi Makro terhadap Indeks Harga Saham di Bursa Efek Jakarta dengan Metode VAR (Vector Autoregressive), dan ECM (Error Correction Model)", Jurnal Ekonomi Teleskop, 4 (7): 101-116.

Suprayitno, Eko. 2005. Ekonomi Islam Pendekatan Ekonomi Makro Islam dan Konvensional. Yogyakarta, Penerbit Graha Ilmu.

Tandelilin, Eduardus. 2001. Analisis Investasi dan Manajemen Portofolio, Edisi Pertama. Yogyakarta: BPFE.

Wibowo, Hamid Ponco. 2005. "Pengaruh Variabel Ekonomi Makro (PDB, Suku Bunga, Kurs) terhadap Kinerja Perbankan Syariah: Analisis Persamaan Simultan 2002-2004 di Indonesia." Tesis, Depok: Universitas Indonesia. 